\section{Suture Material as a Nidus of Common Bile Duct Calculi}

The pathogenetic mechanisms leading to the formation of "de novo" bile stones in patients with prior cholecystectomy are numerous, and have not been thoroughly studied. Changes in the contents of the hepatic bile, bile stasis, bile infection, and foreign bodies in the common bile duct are considered to be the main causes of the phenomenon $(1,2)$. Reports of the formation of bile stones in the bile ducts on suture materials left after cholecystectomy and choledochotomy are very rare $(3,4,5)$. It can be assumed that in these cases, the surgical thread becomes the nidus for the bile stones.

We report here five cases of common bile duct stones in patients who had undergone cholecystecomy 2-15 years earlier (Table 1). Suture thread was found in the endoscopically removed stones, and probably provided the nucleus of crystallization for them (Figures 1,2 ). Surgical thread was found in removed stones in about $1.8 \%$ of our patients with choledocholithiasis after cholecystectomy (during observation). A temporal relationship between the surgery and the appearance of the clinical symptoms of choledocholithiasis was not observed.

Table 1: Patients who had common bile duct stones with suture material inside.

\begin{tabular}{|c|c|c|c|c|c|}
\hline Patient & Sex & Age & $\begin{array}{l}\text { Years after } \\
\text { cholecys- } \\
\text { tectomy }\end{array}$ & $\begin{array}{l}\text { Clinical } \\
\text { presentation }\end{array}$ & Treatment \\
\hline 1 & F & 51 & 9 & $\begin{array}{l}\text { Jaundice, pain. } \\
\text { fever }\end{array}$ & $\begin{array}{l}\text { Sphincterotomy, } \\
\text { Dormia basket }\end{array}$ \\
\hline 2 & $F$ & 62 & 2. & $\begin{array}{l}\text { Jaundice, pain, } \\
\text { fever }\end{array}$ & $\begin{array}{l}\text { Sphincterotomy, } \\
\text { Dormia basket }\end{array}$ \\
\hline 3 & $\mathrm{~F}$ & 54 & 7 & $\begin{array}{l}\text { Recurring biliary } \\
\text { colic }\end{array}$ & $\begin{array}{l}\text { Sphincterotomy, } \\
\text { Dormia basket }\end{array}$ \\
\hline 4 & F & 78 & 15 & Jaundice, pain & $\begin{array}{l}\text { Sphincterotomy, } \\
\text { endoprosthesis }\end{array}$ \\
\hline 5 & M & 64 & 2 & Jaundice & $\begin{array}{l}\text { Sphincterotomy, } \\
\text { mechanical } \\
\text { lithotripsy }\end{array}$ \\
\hline
\end{tabular}

These cases are presented here in order to draw attention to the potential attachment of suture material to the lumen of the bile duct, and the implicit dangers. Although we have not been able to establish the mechanism for this phenomenon - it may result from the surgical technique - it is undoubtedly associated with the use of hard or nonabsorbable suture materials in bile duct surgery.

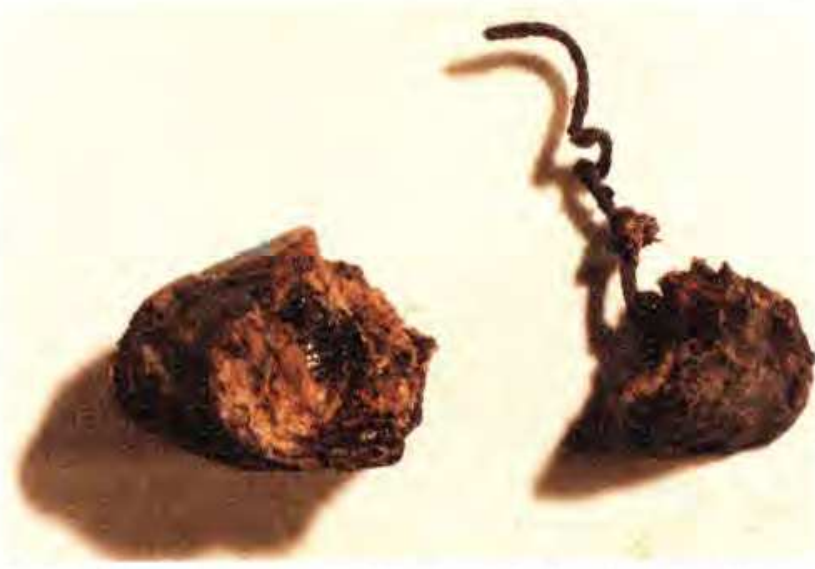

Figure 1: Surgical thread protruding from a crushed bile duct stone.

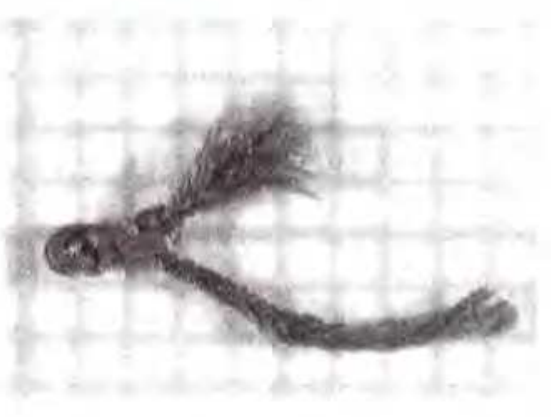

Figure 2: Surgical thread with a knot. found at the center of a common bile duct stone.

\section{References}

1. Cetta FM: Bile infection documented as the initial event in the pathogenesis of brown pigment biliary stones. Hepatology 1986; $6: 482-489$.

2. Margolis JL: Recurrent choledocholithiasis due to hemostatic clip. Arch Surg 1986; 121: 1213.

3. Gough $M H$ : Silk sutures in the common bile duct [letter]. $\mathrm{Br}$ Med J 1977; 2: 1480.

4. Newman $C E$, Hamer. $J D$ : Non-absorbable cystic duct ligatures and common bile duct calculi. Br Med J 1975; 2: 504 .

5. Ormann W: A thread as a nidus of common bile duct calculus: findings during endoscopic lithotripsy. Endoscopy 1986; 21: 191-202.

M. Smoczynski, S. Mittlener

Gastroenterological Clinic, Medical Academy of Gdansk, Poland

Corresponding Author

M. Smoczynski, M.D.

Klinika Gastroenterologii

Akademia Medyczna w Gdansku

ul. Debinki 7

80211 Gdansk

Poland 